\title{
From Knowledge to Innovation and Back: Empirical Testing of Knowledge-Intensive Industries in Serbia
}

\author{
Nikola Radovanović, Veljko Dmitrović, Nevenka Žarkić Joksimović
}

\section{A B S T R A C T}

Objective: In the technology and knowledge intensive industries, innovation and knowledge use are key elements for competitiveness. Organisations are oriented towards increasing their potential for exploiting innovation and developing knowledge base internally through various techniques employed. This research aims at analysing the relationship between the dynamics of knowledge use and innovation efforts of organisations.

Research Design \& Methods: The methodology included quantitative and qualitative research method based on a survey, while the data of this research were analysed with the application of descriptive statistical method (variance).

Findings: The results of the study suggest that realised innovation correlates with the use of knowledge in organisations and that an increase in research and development activities, as well as in patented and non-patented products or services will likely lead to an increase in the volume of internal knowledge use by employees.

Implications \& Recommendations: The results of this research can be useful for researchers and practitioners in technology and knowledge intensive industries. The findings can be used as a basis for adjusting organisational policies towards developing competitiveness based on the enhancement of the use of existing knowledge and by developing innovation strength.

Contribution \& Value Added: This paper is a valuable contribution to research fields of organisational management, innovation management, knowledge management, absorptive capacity, and especially innovation management.
Article type: research paper
Keywords:
knowledge management; innovation; patents; knowledge-intensive industries; Serbia

JEL codes:

Received: 11 April 2017

Revised: 22 June 2017

Accepted: 1 July 2017

\section{Suggested citation:}

Radovanović, N., Dmitrović, V., \& Žarkić Joksimović, N. (2017). From Knowledge to Innovation and Back: Empirical Testing of Knowledge-Intensive Industries in Serbia. Entrepreneurial Business and Economics Review, 5(3), 119-131. http://doi.org/10.15678/EBER.2017.050306 


\section{INTRODUCTION}

The modern era of competition sees innovation as a powerful tool. Organisations from a variety of industries need to be well prepared for this kind of environment, as getting a grip to a sustainable market positioning does not rely on maintaining a product or services line even when they have started market superiority. The ever-increasing trend of innovation is the reason why companies are having even more difficulties in finding the appropriate balance between implementing growth strategies and initiating risky innovative activities.

Modern business is more focused on investing in knowledge and intangible rather than in tangible assets. Knowledge is the driving base for the development of business and successfulness over the long term. In modern conditions, learning organisations have better chance for survival, as it has become obvious that without knowledge there is no innovation. High quality knowledge leads to innovation, but there is a complex set of relationships between the two.

The research was conducted with the aim of identifying and exploring the relationships between innovation drivers and the use of existing knowledge in organisations from knowledge-intensive industries in the Republic of Serbia. Producing an innovation puts an organisation in the innovator category, but it is not easy to maintain innovativeness as the organisation's main orientation. Many organisations cease to innovate for different reasons: lack of material resources, lack of relevant knowledge, lack of strategy, etc. Having in mind that the knowledge base is one of the crucial drivers for innovation, we explore the two-way relationship between knowledge and innovation. The hypothesis of this paper is that the volume of the use of knowledge in organisations from knowledge-intensive industries in Serbia is influenced by different innovation capability drivers. In this research we will provide the analysis of the abovementioned relationships by applying statistical method.

Being defined by the World Bank as the developing country, Serbia was selected as a case which could be applied to other developing countries worldwide. Also, one of the main goals within the national strategy for the sustainable development of Serbia is to reorganise Serbian economy as the knowledge-based economy, which is why knowledgeintensive industries are increasingly vital to Serbian economy.

This paper is structured as follows: the state of the art relevant for the research is followed by the methodology used for the research and the presentation of the empirical analysis of the data. The last chapters include the results of the statistical analysis based on the descriptive statistical method and conclusions based on the research results, complemented by the suggestions for future research.

\section{LITERATURE REVIEW}

The importance of the internal knowledge base has been debated by many. By its definition, knowledge base contains knowledge which is embedded in products, methods, practices, experiences, skills, ideas, etc., and which can come from internal and external sources. Relevant knowledge represents understanding of job skills, products, technologies, markets and other business relevant factors, possessed by the workers and managers in the organisation (Brown, 1997). It consists of facts and ideas that individuals in the organisation have and which can influence the process of implementing innovation. Internal 
knowledge sources primarily include scientific research, new product development, new processes, skills development, experiences and organisational structure, while external sources include external scientific research, other firms' products and processes, lead-users, inter-organisational networks and others (Argote, McEvily, \& Reagans, 2003; VegaJurado, Gutierrez-Garcia, Fernandez-de-Lucio, \& Manjarres-Henriquez, 2008). By establishing a wide knowledge base, the organisation also becomes more sensitive to outside information and knowledge which resides outside its boundaries, and this can result in making new knowledge from the environment more attractable.

The ability to use or share knowledge within an organisation should naturally enhance innovation capabilities. Specifically, a firm practicing inbound activities to strengthen radical innovation is more likely to benefit from knowledge sharing capabilities than from knowledge acquisition capabilities (Cheng, Yang, \& Sheu, 2016). Knowledge-sharing culture within organisation has a positive impact on the knowledge flow and innovation (LeviJakšić, 1995; Van den Bosch, Volberda, \& de Boer, 1999; Tu, Vonderembse, Ragu-Nathan, \& Sharkey, 2006). Sharing and dissemination of knowledge are identified as one of the main knowledge management processes (Probst, Raub, \& Romhardt, 2002). Some authors suggest that the process of acquiring external knowledge for innovation purposes depends on the degree of similarity of cognitive structures, knowledge base, skills and shared languages between an organisation and the environment (Escribano, Fosfuri, \& Tribo, 2006). Prior-related knowledge is one of the suggested components of the organisational absorptive capacity (Cohen \& Levinthal, 1990; Brown, 1997; Zahra \& George, 2002; Tu et al., 2006). It is also the most influential determinant of absorptive capacity of organisations from knowledge-intensive industries (Levi Jakšić, Radovanović, \& Radojičić, 2013).

Firms need an improved communication network among their employees in order to improve the internal knowledge flows which foster learning and innovation (Campo, Gomez, Dimovski, \& Škerlavaj, 2008). Interaction between employees who share knowledge is found to be a crucial element of organisational learning by Wellman (2009). In a pursuit for institutionalisation of learning within an organisation, communication with as few barriers as possible needs to be facilitated (Crossan, Lane, \& White, 1999). Meško Štok, Markič, Bertoncelj and Meško (2010) added that an appropriate communication structure, interpersonal relationships, motivation, stimulation and values as part of organisational culture positively affect business excellence in enterprises. Knowledge sharing relies significantly on the type of organisational structure, which may influence processes of knowledge assimilation, sharing and exploitation in a positive or negative way (Van den Bosch et al., 1999; Chen \& Huang, 2007).

Considering the dynamics of innovative processes and organisational knowledge flow, the change in the level of innovation and existing knowledge in organisations should be causal. Nowacki and Bachnik (2016) emphasised the relationship between innovation and knowledge and pointed out that innovative capacity influences knowledge possessed by organisations. Many studies have dealt with the direct influence of knowledge management on innovation performance. There are suggestions from various authors that firms which operate in highly dynamic industries should strive to reconfigure their resource portfolio to leverage their knowledge management skills for innovation performance (Garg, Walters, \& Priem, 2003; Sirmon, Hitt, \& Ireland, 2007; Sirmon, Hitt, Ireland, \& Gilbert, 2011). Kamasak, Yavuz, Karagulle and Agca (2016) added 
that strategic flexibility is a key enabler of innovation performance through knowledge management. Cohen and Levinthal (1990) stressed the importance of R\&D collaborations for the generation of new knowledge which often emerges as a by-product. However, empirical studies which analyse the effect of contextual variable on the causal relationship between knowledge management and innovation performance are still rare (Sirmon et al., 2011; Anderson, Potočnik, \& Zhou, 2014; Kamasak et al., 2016).

Having in mind the highly dynamic environment where organisations from knowledge-intensive industries operate, these industries have been selected as a target group for this research. The importance of the sectoral analysis in terms of knowledge diffusion and technological innovation has been stressed by Stephan, Schmidt, Bening and Hoffmann (2017). In the area of innovation management and entrepreneurship in knowledge-intensive industries there is wide agreement on the need for the adoption of best innovation management practices (Paredes-Frigolett, 2015). Peltoniemi (2007) suggested that knowledge-intensive industries differ from other industries based on the continuous search for new knowledge. Tödtling, Lehner and Trippl (2004) pointed out high rate of radical innovations in such industries, stating that research and development efforts are focused on generating radical innovations.

An increasing share of industries is becoming more technology and knowledge-intensive. When having importance of technology and knowledge under the spotlight, it has been advised by the OECD (2005) to focus on the leading producers of high-technology goods and on the activities (including services) that are intensive users of high technology and/or have the relatively highly skilled workforce necessary to benefit fully from technological innovations. In developed economies, knowledge-intensive industries have sprung up quickly since the 1990s. In fact, the knowledge-intensive share of developed economies grew from 29\% to 32\% between 1997 and 2012; the United States has the largest knowledge-intensive share, reaching 40\% in 2012. A similar situation exists in developing economies (Ching, Pang, Hung, \& Cheng, 2016).

So far, no studies have been undertaken with the aim of exploring the causal relationship between innovation and knowledge flow in organisations from knowledge-intensive industries in Serbia. Knowledge-intensive industries sectors have been classified and analysed according to the 2005 Classification of the Organization for Economic Cooperation and Development (OECD) and grouped into four main industry groups: 1) high-tech industries, 2) knowledge and innovation based services, 3) research firms, and 4) traditional medium-tech manufacturing (OECD, 2005). For the purpose of this research, 256 organisations from knowledge-intensive industries in Serbia were identified.

\section{MATERIAL AND METHODS}

For the purpose of analysing the knowledge use trends based on the efficiency of innovation in organisations from knowledge-intensive industries in Serbia, we constructed one independent, three dependent and one aggregate variable. Independent variable is knowledge use, dependent variables are innovation motivation, innovation strategy and innovation realised, while aggregate variable is innovation total. The purpose of a thus constructed model was to determine the relationships between the use of knowledge base in organisations and their innovation strength shown as the total score and also divided into separate variables, each representing different aspects of the innovation strength. 
Three dependent innovation variables are innovation motivation, innovation strategy and innovation realised. The innovation motivation variable was constructed as an indicator of the motivation of employees to create innovations. This variable included the frequency of employees' participation at trainings, the existence of incentives and rewards for innovation efforts, the existence of communities of practice and the use of internal trainings led by experienced employees in organisations. Participation in educational events and the frequency of holding internal trainings which are led by organisation seniors are identified as drivers for continuous innovation efforts (Wellman, 2009). Wellman (2009) and Al-Ali (2003) discussed that the most important knowledge sources in organisations include groups of employees, i.e. communities of practice, which gather with the aim of spreading and further developing knowledge. To prove the enormous effect of incentives and rewards for employees' innovativeness efforts, Southwood (1999) emphasised the cases of Dana Corporation and General Motors, where this alignment brought both an increase in profitability and productivity.

The innovation strategy variable was determined by the existence of a department or a group of employees whose tasks include a review of patent documentation, patent portfolios of other organisations and relevant scientific publications in the organisation, the implementation of knowledge management strategy, the implementation of technology management strategy and the use of technology forecasting methodologies. Bader (2007) stressed the significance of patent portfolio management in designing corporate strategies. Patent intelligence is crucial for competitiveness in knowledge intensive industries, which emphasises the importance of organisational capacity to monitor relevant patent documentation and scientific publications. Regarding knowledge and technology management, many studies stressed their importance to organisational performance (Nonaka, 1995; Levi-Jakšić, 2001; Betts, 2003; Dmitrović, Radovanović, \& Žarkić-Joksimović, 2016; Radovanović \& Matović, 2016). The strategic approach to technology management also leads to an increase in licensing activities and collaboration in research and development efforts (Fosfuri \& Tribo, 2008).

The elements of the innovation realised variable are: the number of new products or services introduced to the market, the number of patent applications and the number of initiated research and development projects, all in the time span of two years. Since not all realised innovations are patentable or there is no desire to seek patent protection, this variable also includes the number of new products or services. Also, it is fair to assume that research and development projects could lead to one or more innovations. In-house research and development activities are essential as they generate new knowledge and promote the use of external sources of scientific knowledge (Vega-Jurado et al., 2008). Vega-Jurado et al. (2008) also marked the research and development intensity and technological competences derived from the in-house research and development as key determinants of product innovation.

For the purpose of the research and following the recommendations of Yakhlef (2002), Wellman (2009), Kumar and Ganesh (2009) and Senapathi (2011), we used internal knowledge systems, as internal IT knowledge networks of organisations (e.g. intranets), in the role of the knowledge base. Internal IT systems or network offer diverse ways of communicating knowledge (Kim, 2003) and act as hubs where knowledge can be added, retrieved, modified, used or deleted. Mphidi and Snyman (2004) emphasised 
the existence of strong awareness of the value of the intranet as a knowledge management tool. By presenting findings from Siemens' IT system ShareNet, Ciabuschi (2003) proposed that there is a positive relation between deploying an IT system for knowledge sharing and the direct interaction between corporate units. The effect of the existence of knowledge on the internal IT network to achieve organisational goals is largely influenced by the possibility to retrieve and share such knowledge (Wellman, 2009). Wellman also suggested that an organisation needs to deploy a set of metrics to periodically assess the performance of the internal knowledge base, and these should address the utilisation of the stored knowledge material and the availability of the system to employees of the organisation. The scope of use of the internal knowledge base by employees in organisations is represented in the model by the knowledge use variable. This was evaluated by the percentage of employees with the access to the knowledge base, the percentage of employees with the possibility to enter or modify the data in the knowledge base and the percentage of employees who used the knowledge base in the last two-year period. However, there is an issue in the methods of storing important knowledge, as not all information and especially knowledge can be stored and retrieved in its original way (Yakhlef, 2002; Wellman, 2009). The more tacit the knowledge, the greater the likelihood that it may be distorted in the storage and retrieval process. Therefore, an organisation should lower the tendency of the knowledge distortion process by employing various ways of knowledge recording, retrieving and understanding processes (e.g. by codification or conceptualisation). Therefore,, organisations often use a variety of multimedia applications (such as an audio or video demonstration) to preserve the tacit characteristics as much as possible (Wellman, 2009).

Finally, the variable innovation total included all three dependent innovation variables on equal basis, following the notion that innovation strength of an organisation is determined not only by the realised innovation, but also by its potential and organisational strategic orientation. A questionnaire was developed for the purpose of the research. The questionnaire included questions on the existence of all the elements explained above.

For the purpose of the research, the following step was to determine the level of all variables in the scale from 0 to 1 . The score for each variable was equally dependent on all the elements of the variable. For example, if an organisation responded that all of their employees have the access to the knowledge base, it received the maximum score, which equals 1 . If only $40 \%$ of the employees had the access to the knowledge, it would receive 0.4. For every "Yes" answer in the questionnaire the organisation received a score of 1 , while for "No" it received 0 . Then, the sum of all the scores within the variable would be divided by the number of elements within the variable. Finally, the normalisation of scores was carried out for the purpose of the statistical analysis.

As the final step, we evaluated the variables related to innovation in comparison to the independent variable of the knowledge use, in order to determine which of the variables is significantly affecting the volume of the knowledge use in organisations, but also to assess the relationships between the variables. In this paper, we aimed at testing the hypothesis stating that the innovation capability of organisations influences the use of the knowledge base by employees in organisations from knowledge-intensive industries in Serbia.

The survey for the needs of this research was conducted in March 2013. In total, 256 organisations from knowledge-intensive industries in Serbia were randomly selected and 
the relevant questionnaire was sent to them. Filled-in questionnaires were returned by 53 organisations, setting the response rate to $20.7 \%$. The total of 21 organisations which acknowledged the existence of only textual knowledge forms in their knowledge bases were excluded from the analysis, as the study included the analysis of only those organisations which also possess other forms of knowledge stored, such as visual and audio simulations, based on the research methodology explained in the previous chapter. This left the total number of the analysed organisations at 32.

The results of the frequencies within the descriptive statistics analysis showed that the mean values of most variables are very near each other. The exception is the innovation realised variable, with the mean of 0.8 . The mean and standard deviation values of the researched variables are given in the following table:

Table 1. Descriptive statistics of the indicators used in the analysis

\begin{tabular}{|l|c|c|}
\hline \multicolumn{1}{|c|}{ Variable } & Mean & Std. Deviation \\
\hline Knowledge use & 0.687 & 0.218 \\
\hline Inno strategy & 0.625 & 0.328 \\
\hline Inno motivation & 0.631 & 0.231 \\
\hline Inno realised & 0.803 & 0.252 \\
\hline Inno total & 0.686 & 0.192 \\
\hline
\end{tabular}

Source: authors' calculation.

The table shows that the interviewed organisations had at least some level of the knowledge use by employees. However, at least one organisation had also zero score in one or more categories of innovation capability (shown here as Inno total).

\section{RESULTS AND DISCUSSION}

The relationships between the knowledge use variable and other variables were statistically analysed by the analysis of variance (ANOVA), as shown in Table 2.

Table 2. Results of the ANOVA analysis for the knowledge use variable

\begin{tabular}{|l|l|c|c|c|c|c|}
\hline \multicolumn{2}{|c|}{ Variable } & Sum of Squares & df & Mean Square & F & Sig. \\
\hline \multirow{4}{*}{ Inno strategy } & Between Groups & 0.088 & 4 & 0.022 & 0.182 & 0.946 \\
\cline { 2 - 7 } & Within Groups & 3.252 & 27 & 0.120 & & \\
\cline { 2 - 7 } & Total & 3.340 & 31 & & & \\
\hline \multirow{2}{*}{$\begin{array}{l}\text { Inno motiva- } \\
\text { tion }\end{array}$} & Between Groups & 0.158 & 4 & 0.039 & 0.854 & 0.504 \\
\cline { 2 - 7 } & Within Groups & 1.245 & 27 & 0.046 & & \\
\cline { 2 - 7 } & Total & 1.402 & 31 & & & \\
\hline \multirow{3}{*}{ Inno realised } & Between Groups & 1.373 & 4 & 0.343 & 8.721 & 0.000 \\
\cline { 2 - 7 } & Within Groups & 1.062 & 27 & 0.039 & & \\
\cline { 2 - 7 } & Total & 2.435 & 31 & & & \\
\hline \multirow{3}{*}{ Inno total } & Between Groups & 0.039 & 4 & 0.010 & 0.247 & 0.909 \\
\cline { 2 - 7 } & Within Groups & 1.069 & 27 & 0.040 & & \\
\cline { 2 - 7 } & Total & 1.108 & 31 & & & \\
\hline
\end{tabular}

Source: authors' calculation. 
The results of the ANOVA analysis show that there is no statistically significant difference between most of the group means, with the significance level standing above the usual cut-off point of 0.05 . Thus, we do not have enough evidence of interdependence between the variables representing the innovation strategy level, the innovation motivation level and the total innovation strength, and the variable representing the use of knowledge in organisations. However, the significance value for the mean of the realised innovation is $p<0.0001$; therefore, we can state that the statistically significant difference between the means of the knowledge use and the innovation realisation variables suggest that interdependence between these two variables exists.

Table 3. Post-hoc analysis by Tukey HSD for the knowledge use variable

\begin{tabular}{|c|c|c|c|c|c|c|c|}
\hline \multirow{2}{*}{$\begin{array}{c}\text { Dependent } \\
\text { Variable }\end{array}$} & \multirow{2}{*}{$\begin{array}{c}\text { (I) Knowledge } \\
\text { use }\end{array}$} & \multirow{2}{*}{$\begin{array}{c}\text { (J) Knowledge } \\
\text { use }\end{array}$} & \multirow{2}{*}{$\begin{array}{c}\text { Mean } \\
\text { Difference (I-J) }\end{array}$} & \multirow{2}{*}{$\begin{array}{l}\text { Std. } \\
\text { Error }\end{array}$} & \multirow{2}{*}{ Sig. } & \multicolumn{2}{|c|}{ 95\% Confidence Interval } \\
\hline & & & & & & Lower Bound & Upper Bound \\
\hline \multirow{20}{*}{$\begin{array}{l}\text { Inno } \\
\text { realised }\end{array}$} & \multirow{4}{*}{0.20} & 0.40 & -0.150 & 0.172 & 0.904 & -0.652 & 0.352 \\
\hline & & 0.60 & -0.467 & 0.152 & 0.035 & -0.909 & -0.024 \\
\hline & & 0.80 & -0.486 & 0.159 & 0.037 & -0.950 & -0.021 \\
\hline & & 1.00 & -0.743 & 0.159 & 0.001 & -1.207 & -0.278 \\
\hline & \multirow{4}{*}{0.40} & 0.20 & 0.150 & 0.172 & 0.904 & -0.352 & 0.652 \\
\hline & & 0.60 & -0.317 & 0.115 & 0.070 & -0.651 & 0.018 \\
\hline & & 0.80 & -0.336 & 0.124 & 0.080 & -0.699 & 0.027 \\
\hline & & 1.00 & -0.593 & 0.124 & 0.001 & -0.956 & -0.230 \\
\hline & \multirow{4}{*}{0.60} & 0.20 & 0.467 & 0.152 & 0.035 & 0.024 & 0.909 \\
\hline & & 0.40 & 0.317 & 0.115 & 0.070 & -0.018 & 0.651 \\
\hline & & 0.80 & -0.019 & 0.094 & 1.000 & -0.295 & 0.257 \\
\hline & & 1.00 & -0.276 & 0.094 & 0.049 & -0.551 & -0.001 \\
\hline & \multirow{4}{*}{0.80} & 0.20 & 0.486 & 0.159 & \begin{tabular}{|l|}
0.037 \\
\end{tabular} & 0.021 & 0.950 \\
\hline & & 0.40 & 0.336 & 0.124 & 0.080 & -0.027 & 0.699 \\
\hline & & 0.60 & 0.019 & 0.094 & 1.000 & -0.257 & 0.295 \\
\hline & & 1.00 & -0.257 & 0.106 & 0.139 & -0.567 & 0.053 \\
\hline & \multirow{4}{*}{1.00} & 0.20 & 0.743 & 0.159 & 0.001 & 0.278 & 1.207 \\
\hline & & 0.40 & 0.593 & 0.124 & 0.001 & 0.230 & 0.956 \\
\hline & & 0.60 & 0.276 & 0.094 & \begin{tabular}{|l|}
0.049 \\
\end{tabular} & 0.001 & 0.552 \\
\hline & & 0.80 & 0.257 & 0.106 & \begin{tabular}{|l|}
0.139 \\
\end{tabular} & -0.053 & 0.567 \\
\hline
\end{tabular}

Source: authors' calculation.

The post-hoc test by multiple comparison presented in the above table shows interdependence between the levels of knowledge use and the levels of innovation realisation in detail. Significance level values at Tukey HSD are the lowest for respondents with the highest knowledge use and the highest innovation realised level. However, the results of the Tukey HSD do not significantly differ at other levels of both variables, implying that as the level of knowledge use increases, it is followed by the growth of innovation realisation variable with only slight and insignificant deviations. This finding is also supported by the means plot in Figure 1.

As shown in Figure 1, there is a strong correlation between trends of both variables, with the exception of the slight distortion around the middle values. 


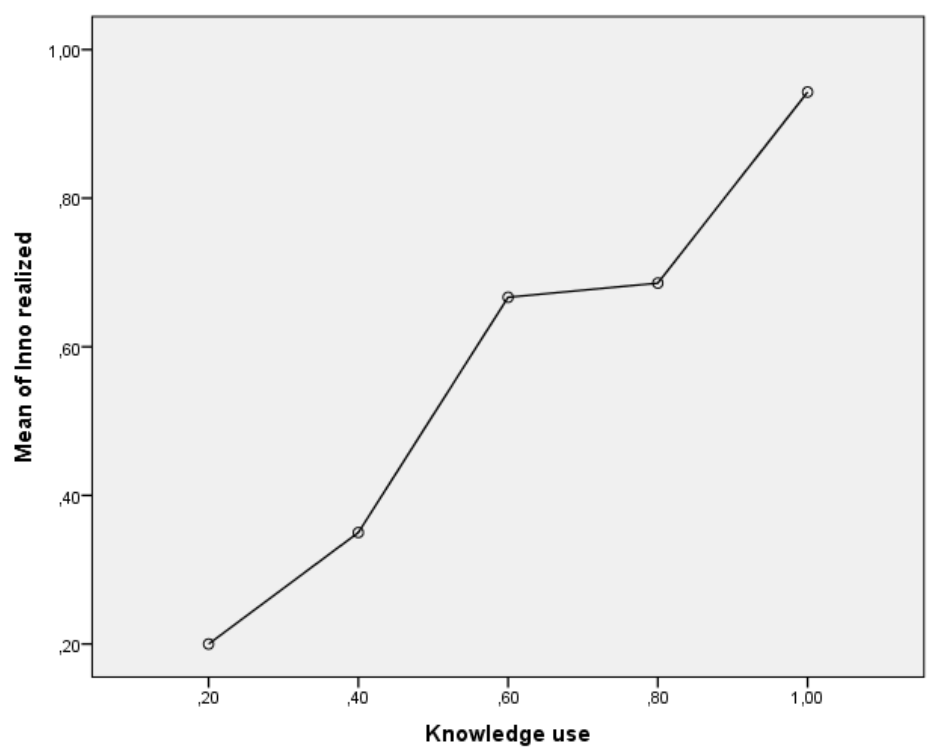

Figure 1. Means plot - the relationship between Innovation realised and Knowledge use variables Source: authors' calculation.

\section{CONCLUSIONS}

The results suggest that the innovation capability indicators in organisations from knowledge-intensive industries in Serbia reflect diverse impact on the level of the existing knowledge use by employees. It is also shown that there is interdependence between the volume of knowledge use and an increase in innovativeness in terms of realised innovation, which is in line with previous research in this area (Levi Jakšić, Barjaktarović Rakočević, \& Martić, 2014). In other words, more patented and non-patented products and services, as well as more research and development activity should lead to the enhanced use of the knowledge base by employees. On the other hand, the results suggest that the use of knowledge base would not be directly increased by an increase in motivation of employees by the introduction of reward policies and trainings or by a stronger focus on the strategic orientation for innovation through knowledge and technology management strategies, communities of practice, and dealing with patent intelligence. It may be therefore concluded that, if increasing the frequency and scope of the internally available knowledge repositories is their goal, organisations should be more focused on the realisation of innovations.

The results of this research partially support the hypothesis, as they indicate that part of the innovation capability of organisations (which is defined by realised innovations) affects the use of the knowledge base by employees in organisations from knowledgeintensive industries in Serbia. The results obtained in this paper contribute to the organisational theory. The results of this research will contribute to better understanding of the relationship between innovation and the use of knowledge in organisations. The constructed innovation variables can be used for other research studies related to similar 
subjects. This paper provides a contribution for the practitioners, as managers and other practitioners can have a clearer view on the innovation drivers which influence the potential for a better use of the existing knowledge in organisations.

This research has its limitations. Although the interdependence between the realised innovation and the knowledge use scope is suggested by the statistical analysis, we cannot exclude the existence of other external factors which may influence the scope of the knowledge use in organisations. Therefore, future research in this area should be directed towards analysing diverse internal factors which may influence this relationship while discovering how it affects the abovementioned established interdependence. Another limitation could be in the representativeness of the sample, which may be considered as debatable. Also, the aspect of knowledge relevance was not included in the research, while it may affect the relationship between innovation and knowledge use. Regarding the geographical scope, this research can be broadened by including other similar developing economies for comparison, especially having in mind that national factors (legislative, availability of resources, etc.) may strongly influence the performance within targeted industries geographically. In relation to the conclusions in this paper, future research in this area may also be directed towards identifying and analysing the factors which distort the relationship between elements of motivation for innovation and innovation strategy on the one hand, and the use of available knowledge in organisations on the other hand.

\section{REFERENCES}

Al-Ali, N. (2003). Comprehensive Intellectual Capital Management. New Jersey: John Wiley \& Sons.

Argote, L., McEvily, B., \& Reagans, R. (2003). Managing Knowledge in Organizations: An Integrative Framework and Review of Emerging Themes. Management Science, 49(4), 571-582.

Anderson, N., Potočnik, K., \& Zhou, J. (2014). Innovation and creativity in organizations: A state-of-the-science review, prospective commentary, and guiding framework. Journal of Management, 40(5), 1297-1333.

Bader, M. (2007). Extending legal protection strategies to the service innovations area: Review and analysis. World Patent Information, 29(2), 122-135.

Betts, C.S. (2003). Contingency Theory: Science or Technology?. Journal of Business \& Economics Research, 1(8), 123-129.

Brown, S.A. (1997). Knowledge, communication, and progressive use of information technology. Ph.D. dissertation, University of Minnesota.

Campo, J., Gomez, F., Dimovski, V., \& Škerlavaj, M. (2008). Exploratory study of organizational learning network within a Spanish high-tech company. Zbornik Radova Ekonomskog Fakulteta u Rijeci/Proceedings of Rijeka Faculty of Economics, 26(2), 257-277.

Chen, C.J., \& Huang, J.W. (2007). How organizational climate and structure affect knowledge management: The social interaction perspective. International Journal of Information Management, 27, 104-118.

Cheng, C.C.J., Yang, C., \& Sheu, C. (2016). Effects of open innovation and knowledge-based dynamic capabilities on radical innovation: An empirical study. Journal of Engineering and Technology Management, 41, 79-91.

Ching, W.C., Pang, T.L., Hung K., \& Cheng, H.W. (2016). Do industry or firm effects drive performance in Taiwanese knowledge-intensive industries?. Asia Pacific Management Review, 21, 170-179. 
Ciabuschi, F. (2003). On IT systems and knowledge sharing in MNCs: a lesson from Siemens AG. Knowledge Management Research \& Practice, 3, 87-96.

Cohen, W.M., \& Levinthal D.A. (1990). Absorptive capacity: A New Perspective on Learning and Innovation. [Special Issue: Technology, Organizations and Innovation]. Administrative Science Quarterly 35(1), 128-152.

Crossan, M.M., Lane, H.W., \& White, R.E. (1999). An organizational learning framework: From intuition to institution. Academy of Management Review, 24(3), 522-537.

Dmitrović, V., Radovanović, N., \& Žarkić-Joksimović, N. (2016). Intellectual capital in function of increasing efficiency in business in organization. Proceedings of the 19th Toulon-Verona Conference, Excellence in Services (pp. 203-210). 5-6 September, 2016, Huelva, Spain, Ca: University of Huelva.

Escribano, A., Fosfuri, A., \& Tribo J. (2006). Managing external knowledge flows: The moderating role of absorptive capacity. Research Policy, 38, 96-105.

Fosfuri, A., \& Tribo, J. (2008). Exploring the antecedents of potential absorptive capacity and its impact on innovation performance. Omega, 36, 173-187.

Garg, V.K., Walters, B.A., \& Priem, R.L. (2003). Chief executive scanning emphases, environmental dynamism, and manufacturing firm performance. Strategic Management Journal, 24(8), 725-744.

Kamasak, R., Yavuz, M., Karagulle, O.A., \& Agca, T. (2016). Importance of Strategic Flexibility on the Knowledge and Innovation Relationship: An Emerging Market Study. Procedia, 229, 126-132.

Kim, G. (2003). Ten Steps to Intranet Success. Online, 27(1), 66-69.

Kumar, A.J., \& Ganesh, L.S. (2009). Research on knowledge transfer in organizations: a morphology. Journal of Knowledge Management, 13(4), 161-174.

Levi-Jakšić, M. (1995). Inovativno preduzeće. Beograd: Fakultet organizacionih nauka.

Levi-Jakšić, M. (2001). Strateški menadžment tehnologije. Beograd: Fakultet organizacionih nauka.

Levi-Jakšić, M., Radovanović, N., \& Radojičić, Z. (2013). Absorptive Capacity Constituents in Knowledge-Intensive Industries in Serbia. Zbornik radova Ekonomskog fakulteta u Rijeci/Proceedings of Rijeka Faculty of Economics, 31(2), 253-278.

Levi Jakšić, M., Barjaktarović Rakočević, S., \& Martić, M. (2014). Innovative Management and Firm Performance: An Interdisciplinary Approach and Cases. Basingstoke, UK: Palgrave Macmillan.

Meško Štok, Z., Markič, M., Bertoncelj, A., \& Meško, M. (2010). Elements of organizational culture leading to business excellence. Zbornik radova Ekonomskog fakulteta u Rijeci/Proceedings of Rijeka Faculty of Economics, 28(2), 303-318.

Mphidi, H., \& Snyman, R. (2004). The utilisation of an intranet as a knowledge management tool in academic libraries. The Electronic Library, 22(5), 393-400.

Nonaka, I., \& Hirotaka, T. (1995). The knowledge creating company: how Japanese companies create the dynamics of innovation. New York: Oxford University Press.

Nowacki, R., \& Bachnik, K. (2016). Innovations within knowledge management. Journal of Business Research, 69, 1577-1581.

OECD (2005). Science, Technology and Industry Scoreboard. Paris, France: (OECD Publishing Document).

Paredes-Frigolett, H. (2015). Towards a Knowledge-Based Innovation Tutoring System. Procedia Computer Science, 55, 203-212.

Peltoniemi, M. (2007). Why do Managers from Different Firms Exchange Information? A Case Study from a Knowledge-Intensive Industry. The Electronic Journal of Knowledge Management, 5(1), 81-88.

Probst, G., Raub, S., \& Romhardt, K. (2002). Knowledge management in organization. Krakow: Publishing Office. 
Radovanović, N., \& Matović, D. (2016). Organizational forms and knowledge absorption. Industrija, 44(3), 175-190.

Senapathi, R. (2011). Dissemination and utilisation of knowledge. SCMS Journal of Indian Management, 8(2), 85-105.

Sirmon, D.G., Hitt, M.A., Ireland, R.D., \& Gilbert, B.A. (2011). Resource orchestration to create competitive advantage: Breadth, depth, and life cycle effects. Journal of Management, 37(5), 1390-1412.

Sirmon, D.G., Hitt, M.A., \& Ireland, R.D. (2007). Managing firm resources in dynamic environments to create value: Looking inside the black box. Academy of Management Review, 32(1), 273-292.

Stephan, A., Schmidt, S.T., Bening, C.R., \& Hoffmann, V.H. (2017). The sectoral configuration of technological innovation systems: Patterns of knowledge development and diffusion in the lithiumion battery technology in Japan. Research Policy, 46, 709-723.

Southwood, M. (1999). Igniting a Firestorm of Creativity. In G. Dauphinais \& C. Price (Eds.) Straight from the CEO (p. 238). Riverside, NJ: Simon \& Schuster.

Tödtling, F, Lehner, P., \& Trippl, M. (2004). Knowledge intensive industries, networks, and collective learning. In 44th European Congress of the European Regional Science Association, 25-29 August, 2004, Porto, Portugal: University of Porto.

Tu, Q., Vonderembse, M.A., Ragu-Nathan, T.S., \& Sharkey, T.W. (2006). Absorptive capacity: Enhancing the assimilation of time-based manufacturing practices. Journal of Operations Management, 24, 692-710.

Van den Bosch, F.A.J., Volberda, H.W., \& de Boer, M. (1999). Coevolution of Firm Absorptive Capacity and Knowledge Environment: Organizational Forms and Combinative Capabilities. Organization Science, [Focused Issue: Coevolution of Strategy and New Organizational Forms]. 10, 551-568.

Vega-Jurado, J., Gutierrez-Garcia, A., Fernandez-de-Lucio, I., \& Manjarres-Henriquez, L. (2008). The effect of external and internal factors on firms' product innovation. Research Policy, 37, 616-632.

Wellman, J. (2009). Organizational learning - How companies and institutions manage and apply knowledge. New York: Palgrave Macmillan.

Yakhlef, A. (2002). Towards a discursive approach to organizational knowledge formation. Journal of Management, 18, 319-339.

Zahra, S.A., \& George, G. (2002). Absorptive capacity: a review, reconceptualization, and extension. Academy of Management Review, 27(2), 185-203. 


\section{Authors}

The contribution share of authors is equal and amounted to $1 / 3$ each of them.

\section{Nikola Radovanović}

Consultant in the Intellectual Property Office of the Republic of Serbia, where he performs advisory and lecturing activities on intellectual property management, valuation and commercialisation. He is engaged in various H2020, Erasmus and Tempus projects. Received his PhD in Technical Sciences and MSc in Economics, both from the Belgrade University. His research has been published in many well-renowned international journals and proceedings.

Correspondence to: Dr. Nikola Radovanović, The Intellectual Property Office, Kneginje Ljubice 5, 11000 Beograd, Serbia e-mail: nikola.radovanovic.ip@gmail.com

\section{Veljko Dmitrović}

Assistant Professor at the Faculty of Organizational Sciences, University of Belgrade (Serbia), at the Department of Financial Management and Accounting. He gained PhD and MSc in Financial Management at the Faculty of Organizational Sciences, University of Belgrade, BSc and MA degrees in Marketing Management at the Faculty of Economics in Subotica, University of Novi Sad (Serbia). So far he has authored and coauthored more than 50 papers published in international and national journals and conferences. He has been involved in several research projects.

Correspondence to: Dr. Veljko Dmitrović, University of Belgrade, Faculty of Organizational Sciences, Jove llića 154, 11000 Beograd, Serbia, e-mail: dmitrovicv@fon.bg.ac.rs

\section{Nevenka Žarkić Joksimović}

Full Professor and Head of the Department of Financial Management and Accounting at the Faculty of Organizational Sciences, University of Belgrade (Serbia). She has published more than 20 books and monographs, and over 80 papers in national and international journals and conferences proceedings. She has also rich experience in higher education institution management and professional expertise gained through participating in several national and international projects. As a grant holder and key expert, she enrolled in four TEMPUS projects: FINHED - Towards sustainable and equitable financing of higher education in Bosnia and Herzegovina, Montenegro and Serbia, STREW - Building Capacity for Structural Reform in Higher Education of Western Balkan Countries, CONCUR - Conversion courses for unemployed university graduates in Serbia, and Integration of the University Governance, Management and Service through an Efficient Management Information Network.

Correspondence to: Prof. dr. Nevenka Žarkić Joksimović, University of Belgrade, Jove llića 154, 11000 Beograd, Serbia, e-mail: nevenka.zarkic-joksimovic@fon.bg.ac.rs

\section{Acknowledgements and Financial Disclosure}

The authors would like to thank the anonymous referees for their useful comments, which allowed to increase the value of this article.

\section{Copyright and License}

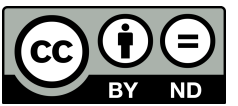

This article is published under the terms of the Creative Commons

Attribution - NoDerivs (CC BY-ND 4.0) License

http://creativecommons.org/licenses/by-nd/4.0/ 
